\title{
Coping with climatic shocks: local perspectives from Haiti's rural mountain regions
}

\section{Caroline Staub $^{1} \cdot$ Anne Gilot $^{1} \cdot$ Molene Pierre $^{2} \cdot$ Gerald Murray $^{3}$ • Rosalie Koenig ${ }^{1}$}

Published online: 12 June 2020

(C) The Author(s) 2020, corrected publication September 2020

\begin{abstract}
Haiti's agrarian society is highly sensitive to changes in weather and climate conditions. Little is known about Haitian farmers' perceptions of climate-related risks and their ability to cope with hazards, which may reduce the relevance and likelihood of success of proposed adaptation solutions. We discuss the findings from the focus groups held with 104 smallholder farmers from mountain areas. Farmers in the study area regard the impacts of climate hazards on their livelihood as significant but largely prioritize short-term solutions over longterm protective measures, which potentially increase their vulnerability over time. The study provides insights on local decision processes and potential pathways for discussing climate information with farmers. It identifies the types of information perceived as necessary for informed decision-making. The findings, while in some cases distinctive to the study area, have implications for the design of climate change adaptation interventions in other contexts.
\end{abstract}

Keywords Agriculture $\cdot$ Haiti $\cdot$ Rural $\cdot$ Extension $\cdot$ Climate $\cdot$ Decisions

Caroline Staub

carogstaub@ufl.edu

Anne Gilot

agilot@ufl.edu

Molene Pierre

pierremolene@ufl.edu

Gerald Murray

murray@ufl.edu

Rosalie Koenig

rlkoenig@ufl.edu

1 Institute of Food and Agricultural Sciences, University of Florida, Gainesville, FL, USA

2 USAID Feed the Future Appui A la Recherche et au Developpement Agricole Petion-Ville, Pétion-Ville, Haiti

3 Department of Anthropology, University of Florida, Gainesville, FL, USA 


\section{Introduction}

Agricultural production faces increasing risks from variable weather and climate conditions. In the Caribbean region, these risks include inundations, water stress, and other extreme weather events associated with more frequent, heavy rainfall events, and drier summers (Karmalkar et al. 2013; Neelin et al. 2006; Peterson et al. 2002; Rauscher et al. 2008). Rain-fed agriculture systems depend on the amount and distribution of rainfall and are particularly sensitive to a changing climate. About half of the Haitian population resides in rural areas and depends on small-scale, rain-fed agricultural production as their main source of income. The country's agricultural sector is central to its economy, contributing $22 \%$ to the gross domestic product (World Bank 2019). Yet Haiti has one of the highest levels of food insecurity in the world, with $60 \%$ of the population living below the poverty line and over half reported as undernourished (WFP 2019). Weather and climate extremes are exacerbating existing challenges. In 2016, Hurricane Matthew destroyed 90\% of crops on Haiti's Southern plateau and affected over two million people (CRS 2016). During the 2015-2016 El Niño event, Catholic Relief Services estimated that one million people's livelihoods were affected by drought in Haiti (CRS 2016).

Farmers have always had to adjust their practices to cope with changing weather conditions. However, unprecedented impacts brought about by anthropogenic climate change now require new types of responses (Meinke et al. 2009; Nurse et al. 2014). Advancing the resources available for farmers to anticipate the variability of climate conditions and plan accordingly can help them reduce potential negative outcomes. Considerable progress has been made in climate change research and adaptation strategies to assist farmers around the world. Adaptation strategies include the use of early warning forecasts (Changnon and Vonnahme 2003; Golnaraghi and Senior 1995; Patt et al. 2005), resistant crop and livestock varieties (Ali and Erenstein 2017), diversification of farming practices and off-farm livelihood options (Clarkson et al. 2019), and crop insurance (Mase et al. 2017).

While some resources are adopted by farmers and integrated into their decisionmaking, many are not, which constrains adaptation (Buizer et al. 2005; Carr et al. 2016, Cash et al. 2006; Lemos et al. 2012). Analyses of decision-making suggest that prior to choosing one or more actions, individuals appraise the probability and magnitude of extreme events, consider a list of alternative actions, and evaluate the consequences of these actions on their livelihoods (Slovic et al. 2016).

Farmers' perceptions of climate risks, the options that are at their disposal and the flexibility they may have to use them, determine the type of adaptation strategies they are likely to adopt (Adger et al. 2009; Burton et al. 1978; Clarkson et al. 2019; Grothmann and Patt 2005; Karki et al. 2020). These strategies may have significant consequences on the livelihoods of farmers who have limited access to resources. Farmers' perceptions vary according to multiple factors including traditional roles and practices, access to markets, access to financial resources and information, and support from agricultural extension services (Changnon and Vonnahme 2003; Comoé and Siegrist 2015; Mase et al. 2017). An understanding of these perceptions is necessary to ensure the relevance of proposed adaptation solutions and their likelihood of success.

Little is known about Haitian farmers' perceptions of climate-related risks, their experiences of periodic droughts, hurricanes and other climatic events, and their ability 
to cope. Government-run extension services are lacking (Arias et al. 2013; Zelaya et al. 2017), which likely undermines farmers' decision-making process by limiting their potential to access reliable information, advice, and exposure to improved practices and technologies. A study by Zelaya et al. (2017) reveals that small-scale farmers in Northern Haiti make decisions based on factors including a need for financial security, familial traditions, concern for family welfare, availability of resources, financial limitations, and previous experiences.

Our study provides baseline information on farmers' decision-making context, the importance of climate-related risks relative to other risks, and the factors that may help them moderate the losses associated with climate variability. We then discuss their implications for research and extension initiatives in rural areas in Haiti and other countries where agricultural extension and climate advisory services have limited support.

\section{Study area}

Participants came from the mountainous areas surrounding the communities of Kenscoff and Goyavier, located at $1405 \mathrm{~m}$ and $1175 \mathrm{~m}$ above sea level, respectively (Fig. 1). Annual rainfall and temperature in these regions average $1400 \mathrm{~mm}$ and $16{ }^{\circ} \mathrm{C}$ respectively (Moron et al. 2015). Rainfall distribution coincides with the two main planting seasons in the region. Farmers plant their crops in March (main season) and in

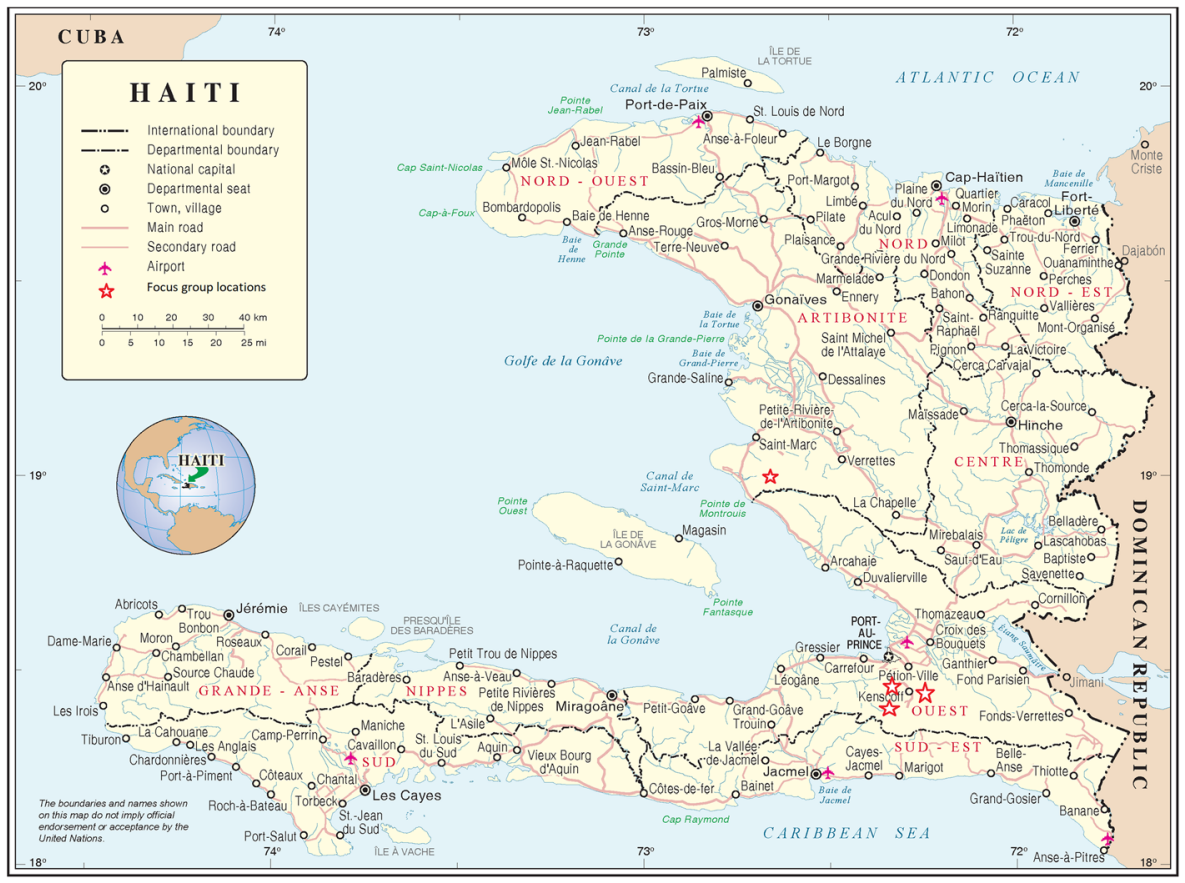

Fig. 1 Focus group interviews were conducted around the communities of Kenscoff and Saint Marc 
August (second season). They engage in both agrarian and non-agrarian livelihoods to satisfy their household needs (FEWS NET 2015). High-value horticultural crops including bell peppers, broccoli, carrot, and leek are especially important in these regions because of the close proximity to lucrative markets in Port au Prince and Saint Marc. In addition to crops, farmers raise poultry, goats, swine, and cattle for both home consumption and income generation. Non-agrarian options include local transportation, construction, electrical work, and other manual labor jobs for men and teaching, catering, basket making, and cosmetology for women.

\section{Methods}

We conducted focus group interviews with farmers from August 2018 to January 2019 using a survey and protocol approved by the University of Florida's Institutional Review Board.

The research team invited a group of Haitian extension professionals to review the instrument to improve content, clarity, and flow. Their input was incorporated into a final version of the instrument, which was translated to Haitian Creole and reviewed by native Haitian Creole speakers for clarity and accuracy.

Focus group participants from the target communities were members of farmer associations in the region. Men and women were questioned in separate groups to ensure that women's perspectives would be equally represented in the study. All interviews were conducted in Haitian Creole. With the consent of participants, two people took notes and made audio recordings of each focus group session. A moderator encouraged people to discuss among themselves and build on each other's comments. The focus groups discussed four core topics, which are presented in Table 1. Questions directly referring to climate issues were posed near the end of the sessions to avoid potential biases.

Within $24 \mathrm{~h}$ of each discussion, the study team conducted a question by question debrief of the notes and audio recording. We used a two-step data analysis process. First, the data was reduced by preparing abridged transcripts to eliminate redundancy and create short descriptive summaries of group responses. We identified at least one quote to illustrate group responses for each topic. Next, we used the constant comparative method (Evans et al. 2001; Glaser et al. 1968) and noted commonalities and differences between groups on a question-by-question and gender-by-gender basis. As recurring themes became apparent, we formulated the findings and discussed potential linkages among them.

\section{Limitations}

Despite our efforts to select a homogeneous audience and encourage all group members to contribute to group discussions, group leaders and facilitators noticed that age differences negatively affected participation in most focus groups. Young men were often shut down by older men. Additional studies from various sources including individual interviews and focus groups are needed to better understand farmers' challenges and responses to weather and climate changes. 
Table 1 Focus group discussion topics

\begin{tabular}{|c|c|}
\hline Topic & Farmers were asked to: \\
\hline 1 Identification of production risks & $\begin{array}{l}\text { Share their observations of any changes in yield over the } \\
\text { past } 10 \text { years } \\
\text { List their perceived risks to agricultural production }\end{array}$ \\
\hline 2 Key decision-making criteria & $\begin{array}{l}\text { Outline the key factors that they take into consideration } \\
\text { before the season }\end{array}$ \\
\hline $\begin{array}{l}3 \text { Impacts of weather and/or climate-related haz- } \\
\text { ards and associated coping strategies }\end{array}$ & $\begin{array}{l}\text { Recall years that were particularly dry and wet within a } \\
\text { 20-year period (from } 1998 \text { to 2018) } \\
\text { Discuss the impacts of weather and/or climate-related } \\
\text { hazards on livelihoods during aforementioned years } \\
\text { Discuss coping strategies (both reactive and proactive) } \\
\text { used during aforementioned years } \\
\text { Identify anticipatory and preventative strategies }\end{array}$ \\
\hline $\begin{array}{l}4 \text { Identification of existing climate and } \\
\text { weather-related resources and associated pref- } \\
\text { erences }\end{array}$ & $\begin{array}{l}\text { Identify the institutions through which they receive } \\
\text { information or guidance on how to manage weather and } \\
\text { climate-related risks } \\
\text { Name the type of information they have access to and } \\
\text { describe how they use it to manage weather and/or } \\
\text { climate risks } \\
\text { List additional information that might be useful and } \\
\text { explain what it would be used for } \\
\text { List the communication channels they would prefer to } \\
\text { receive weather and climate-related information from }\end{array}$ \\
\hline
\end{tabular}

\section{Results}

At each site, we conducted four (two male only and two female only) interviews, for a total of 16 interviews with 104 participants (51 men and 53 women). The average number of participants per group was seven. The participants varied in age from 18 to 70 years. Although one site was located further away from the others, we found no obvious differences in responses between the sites. Results are presented according to the four topics of interest (Table 1).

\section{Risks to agricultural production}

Most groups indicated that yields of their major crops and livestock have decreased over the past 20 years. When asked to explain why yields were going down, men and women reported similar production challenges, many of which relate directly or indirectly to changing weather and climate conditions. Challenges to crop production were lack of rain, the occurrence of pests, excessive rainfall, hurricane winds, sudden shifts in temperature, diseases, availability of good-quality seeds, lack of irrigation, lack of capital, availability of labor, and poor soil quality. With regard to livestock production, frequently reported challenges were disease, robbery, hurricane-related deaths or injuries, drought, predation by feral animals, deterioration of forage, and sudden fluctuations in temperature. 
Participants in two groups experienced an increase in yields which they attributed to their use of improved crop varieties. While these farmers are accessing technologies that increase their productivity, a lack of availability and affordability of improved agricultural technologies is a constraint for farmers in other groups. Among other things, the high debt burden of Haiti and many countries in the region has limited the state's ability to invest in public services, technology, and infrastructure (CANARI 2005).

\section{Key decision-making criteria}

Many different factors affect farmers' agricultural planning and ability to cope with weather and climate-related hazards. Uncertainties about the timing and amount of rainfall have a major influence on their farming decisions. Participants complained that temperatures are getting warmer, that there is less rainfall now than in times past, and that it is becoming more difficult to predict the onset and duration of the rains. This in turn influences what crops they grow and when they plant them. Crop selection is also influenced by seasonal demand, their market value, and the availability and quality of inputs such as seeds, animal feed, fertilizers, and pesticides. The availability of capital affects their ability to plan and purchase agricultural inputs and their ability to support other livelihood enterprises.

Only the female groups mentioned the importance of planting crops that could be used for home consumption. They are concerned about the nutritional value of what they grow and use for home consumption. In Haiti, women are responsible for household tasks including meal preparation.

\section{Impacts of weather and/or climate-related hazards and associated coping mechanisms}

An understanding of farmers' key production risks and decision-making criteria is necessary for an objective evaluation of the adaptation measures selected by farmers in times of crises. Farmers use different adaption strategies in years when they receive either too much or too little rainfall.

\section{Dry years}

During dry periods, most groups reported experiencing yield loss due to reductions in the quality and/or quantity of agricultural produce. Crops die before reaching maturity either in plant nurseries or in the field (Table 2). Plant deaths in the field suggest that farmers may not always wait for the rains to start before planting. Plants that survive dry periods have lower yields because of lack of water or pest infestations. While livestock usually survive, the animals suffer weight loss due to less forage availability. To illustrate the impact, one farmer said:

The animals could not graze: they didn't find any vegetation. Even people couldn't walk, it was so hot. There were people who felt sick. There were farmers who did not sow at all since it was so hot. Those who had land in shaded areas were able to get some yield, but profits were minimal after [accounting for the costs associated with] harvesting. (Kenscoff-Women) 
Table 2 Impacts of dry years and coping strategies

\begin{tabular}{|c|c|}
\hline Impacts - dry years & Coping strategies - dry years \\
\hline $\begin{array}{l}\text { Yield Loss } \\
\text { Insect damage to crops } \\
\text { Disease damage to crops } \\
\text { Delayed crop harvest }\end{array}$ & $\begin{array}{l}\text { Wait for adequate conditions and replant } \\
\text { Use reserves of seed to replant } \\
\text { Salvage surviving crops } \\
\text { Replant crops that are more drought-resistant } \\
\text { (roots, tubers) } \\
\text { Diversification of plot locations }\end{array}$ \\
\hline $\begin{array}{l}\text { Lack of forage for livestock } \\
\text { Weight loss in livestock }\end{array}$ & $\begin{array}{l}\text { Add salt to the water } \\
\text { Relocate livestock to greener pastures } \\
\text { Sell animals }\end{array}$ \\
\hline $\begin{array}{l}\text { Lack of water for irrigation and household consumption } \\
\text { Rise in market prices } \\
\text { Lower ability to access funds } \\
\text { Weight loss and fatigue in the household }\end{array}$ & $\begin{array}{l}\text { Use reserves of grain for household consumption } \\
\text { Engage more often in commercial activities } \\
\text { Cut trees and sell charcoal } \\
\text { Access water in alternative ways } \\
\text { Access loans } \\
\text { Engage in alternative income-generation } \\
\text { occupations }\end{array}$ \\
\hline
\end{tabular}

Women reported having to travel further to obtain water for drinking, cooking, washing, or irrigation if the household could not afford to buy additional water. In rural Haiti, women and children frequently transport water over long distances on their heads.

In times of drought and once harvests have failed, most groups reported waiting for favorable conditions and switching to crops that they believe better tolerate drought, such as plantains, or have a shorter growing cycle, such as leeks and bell peppers. They grow more traditional subsistence crops, such as tubers and roots, because they have a better chance to survive and can provide food for home consumption. They may have to sell animals or take a loan in order to purchase the inputs necessary to replant the new crops. Loans from banks, credit unions, and microfinance organizations are often associated with high interest rates and are difficult to repay. Participants mentioned that poorer farmers sometimes cut down trees for the production and sale of charcoal, indicating that drought is a cause of deforestation.

\section{Wet years}

Wet years were usually associated with hurricanes. Participants reported experiencing production and income losses and livestock suffering from disease. Farmers who lack the resources necessary to build an enclosure often tie up their animals to a pole, a practice which may cause drowning in times of flash floods. While male groups mostly discussed the challenges of flooding, uprooting, and destruction of crops during hurricanes (Table 3), female groups frequently stressed an increase in the frequency of livestock diseases including post-hurricane gastrointestinal and ear infections and flu-like symptoms in chickens. Haitian women are typically responsible for tending to home gardens, fruit trees, and small livestock, which sustain the family during the dry season (Smucker and Nowak 1981; White 1993). 
Table 3 Impacts of wet years and coping strategies

\begin{tabular}{ll} 
Impacts_-wet years & Coping strategies-wet years \\
\hline Yield loss & Wait for adequate conditions and replant \\
Damage and uprooting of crops & Salvage surviving crops \\
Soil erosion or sudden accumulation & $\begin{array}{l}\text { Re-apply fertilizer and apply pesticide } \\
\text { Select crops based on lowest production cost, growing } \\
\text { cycles, and tolerance }\end{array}$ \\
& Sell animals \\
Death from drowning or falling branches & Vaccinate the animals \\
Diseases in livestock & Relocate the livestock to drier, sheltered area \\
& Use reserves for consumption \\
Incidence of looting (crops and livestock) & Engage in commerce more frequently \\
Casualties or injuries in the household & Cut trees for charcoal \\
Rise in market prices & Dependence on remittances from diaspora \\
Limited access to markets & Access credit from pooled resources, banks, or friends \\
Damage and uprooting of trees & Rely on friends and community for new inputs (seeds) \\
Destruction of houses and other property & NGO relief and aid (cash for work; reforestation; \\
Crop diseases & soil conservation)
\end{tabular}

Coping strategies during wet years were much the same as those reported during dry periods. Most groups reported that crops - usually root crops - can be salvaged and will be harvested and either sold or consumed depending on the maturity level reached at the time of harvest. Similar to when they lose crops during droughts, farmers also reported seeking financial help and replanting once the hurricane passes and fields are free of standing water.

Farmers reported being better able to protect themselves from the hazards experienced during wet years compared with dry years. Preventive measures they use include procuring and storing food and fuel, protecting assets, seeking shelter, and maintaining and repairing terraces to prevent the loss of topsoil and fertilizers. Some mentioned building diversionary drainage ditches. Since the participants live and farm in the highlands, there is a need to continually invest capital in infrastructure designed to reduce soil erosion and prevent severe flooding events.

\section{Identification of existing climate and weather-related resources, and associated preferences}

In Haiti, weak public sector support for agriculture extension and climate services limits farmers' ability to make evidence-based decisions pertaining to climate risk. Most groups reported discussing climate-related topics informally among themselves, with master farmers or at farmer association meetings:

Between us, we sometimes talk about it, but we don't find anyone from an [organization] to come talk to us. (Kenscoff-Men)

When asked whether they had access to weather information, many stated that they receive weekly weather and hurricane forecasts over the radio and via text messages. When asked if this weather information was useful for decision-making, the majority 
said that they rely on hurricane forecasts to know when to take animals to shelter. Some groups reported that they were currently unable to use the weekly weather forecast, citing different reasons such as not knowing how to use it and that the information was often not timely or accurate. The weekly weather forecast in Haiti is only available at the department level. Haiti is divided into five regional departments. The topography of Haiti is complex, and meteorological conditions vary across a single department (Moron et al. 2015).

Most groups were interested in receiving additional information pertaining to dayto-day weather and seasonal conditions. For example, some groups mentioned that the projected timing and duration of rainfall would help them revise their planting activities and the application of fertilizers and pesticides. Some groups mentioned that information pertaining to upcoming seasonal climate conditions could help them to reassess the amount of acreage used for specific crops, select optimal conditions to sow and harvest, choose crops to better tolerate predicted conditions, and more efficiently use resources.

"We need to know when there will be rain or when there will be no rain. ... If we know that such a period will have droughts, we will sow less ... and we will know what to plant because there are crops that are less resistant and others that are more resistant." (Goyavier-Men)

Some groups highlighted the importance of receiving not just information but advice and strategies on how to manage agricultural plots under extreme weather conditions. This indicates that the current variability in weather conditions may make traditional knowledge on how to manage related risks less reliable.

Preferences of communication channels were SMS (including WhatsApp), radio, megaphones and loudspeakers, farmer association meetings, TV, brochures, and wordof-mouth. In an area where direct contact with extension agents is limited, it is not surprising that cellphones and radios should be perceived as the preferred communication channels for receiving climate information. In 2018, $95 \%$ of Haitians had access to the mobile phone network, and $58 \%$ had a mobile cellular subscription (World Bank 2018). Nearly every household has a radio set.

\section{Discussion}

While climate change impacts generate concerns worldwide, there are areas where people do not think these are relevant to their lives and they are less likely to adopt adaptation solutions because of this (Adger and Vincent 2005; Burton et al. 1978; Grothmann and Patt 2005). Participants in this study, as in other areas where livelihoods and food security are at stake (Burton et al. 1978), perceive even small changes in climatic conditions. Temperatures are perceived to be increasing and the timing and duration of rainfall have become more unpredictable. Crop and livestock yields have reportedly declined, and many of their production challenges are either directly or indirectly associated with weather and climate shocks. In some cases, climate hazards disproportionately affect one gender over another due to traditional gender roles. For instance, women reported additional constraints on their time during dry years, when they travel further to obtain water for drinking, cooking, washing, or irrigation. 
Factors affecting farmers' decision-making process are complex and help explain the measures they use to cope with climate hazards. While traditional farming strategies such as the diversification of income sources, saving of seed and grain, and reinforcing of infrastructure aim at protecting and sustaining their livelihoods, farmers prioritize short-term gains at the expense of long-term sustainability. Being close to affluent markets in Port au Prince and Saint Marc, they maximize their opportunities to make profits by selecting high-value horticultural crops even if they are more sensitive to changes in weather conditions. When disaster strikes, participants salvage what they can, sell assets, use savings, seek loans, or depend on disaster relief funds to start over which perpetuates their vulnerability to recurring shocks. Coping strategies that prioritize short-term gains over long-term sustainability are common in countries afflicted with a lack resources and infrastructure, poor levels of education and institutional support, and ineffective policy (Meinke et al. 2009).

Despite the country's exposure to hurricanes and vulnerability to droughts and other climate shocks, access to irrigation, improved varieties, and other technological solutions that can help farmers protect themselves against climate-related disasters are either scarce or costly. Yet, participants revealed that actionable information allows them to reduce losses from weather-related shocks. For example, hurricane warnings are used to stock up on food and protect assets. Access to timely and accurate information on upcoming weather and seasonal climate conditions can empower farmers to make informed decisions and minimize losses during unfavorable years (Golnaraghi and Senior 1995; Patt et al. 2005). Grothmann and Patt (2005) showed that in some cases, farmers are unwilling to believe that the use of forecasts can protect them from harm and are therefore unlikely to use them. In our study, participants identified different barriers to the use of existing information. Weather forecasts are often not timely or accurate enough for them to be able to adjust pro-actively to changes and uncertainty. Issues pertaining to the usefulness and usability of weather and climate information are not unique to Haiti and have occurred in many other parts of the world (Cash et al. 2006; Changnon and Vonnahme 2003; Lemos et al. 2012).

Participants also identified factors that may help them take long-term protective measures to moderate losses associated with climate variability. Access to reliable climate information about the upcoming season, with enough lead time to take action, would help them reassess the amount of acreage used for specific crops, select optimal conditions to sow and harvest, choose crops to better tolerate predicted conditions, and use resources more efficiently. Men and women may have different needs for and abilities to act on weather and climate information (Carr et al. 2016), and additional investigation on this topic is important.

Study participants asked for advice on how to manage agricultural plots under extreme weather conditions, revealing that, having no one else to talk to, they discuss climaterelated topics among themselves or at farmer association meetings. A lack of governmentrun agricultural extension services in Haiti undermines farmers' potential to access reliable information, advice, and exposure to improved practices and technology (Arias et al. 2013; Zelaya et al. 2017). In turn, farmers' ability to make informed decisions and take action to reduce climate-related risks is also limited. The application of climate information in decision-making is not straightforward (Lemos et al. 2012) and needs to be embedded within context-specific participatory dialogues that match farmers' needs to suitable tools and strategies (Clarkson et al. 2019; Meinke et al. 2009). 


\section{Conclusions and recommendations}

This study provides baseline information about Haitian farmers' perceptions of the major risks to agricultural production; the key criteria influencing their decisions and coping strategies; their experiences of periodic droughts, hurricanes, and other climatic hazards; and some of the obstacles that they confront in taking action to cope with them. Farmers are acutely aware of climate-related risks and use the few resources that are available to independently assess and manage those risks. They struggle to anticipate the variability of weather and seasonal climate conditions and take it into account when thinking of livelihood or management strategies. As a result, they tend to prioritize short-term solutions over longterm protective measures, which potentially increase their vulnerability over time.

It is important for the agricultural development community to recognize that efforts to reduce poverty and enhance food security go hand in hand with building farmers' capacity to manage climate-related risks (Ali and Erenstein 2017; Clarkson et al. 2019). Advancing the resources available for farmers to anticipate the variability of climate conditions and plan accordingly can help them reduce potential negative outcomes. Support to the National Meteorological Service for the collection, analysis, and dissemination of weather data is necessary to improve the reliability and breadth of information that farmers can use to assess the risks they are facing. Investment in climate-informed extension programs focusing on context-specific adaptation options is needed to provide farmers with guidance on adaptation. In areas where farmers do not regularly meet with extension agents, farmer group meetings and other active rural groups may constitute an appropriate institutional setting for regular pre-season planning sessions. Encouraging farmers to be more strategic in the way they allocate resources given projected seasonal climate scenarios can engender a sense of agency and empowerment among farmers (Cash et al. 2006; Changnon and Vonnahme 2003; Clarkson et al. 2019). In the long term, it will be necessary to discuss adaptation options that consider climate as one of many possible drivers of change (Meinke et al. 2009). Additional studies are needed to better understand gender-specific challenges and responses to weather and climate hazards and inform the development of adaptation plans for small-scale farmers in Haiti and around the world.

Acknowledgements We are grateful to the Appui a la Recherche et au Developpement (AREA) project team for helping coordinate this study. Special thanks go to Edzer Milord for helping with data collection and logistics, as well as all the participants who kindly and patiently shared their experiences with us.

Funding information This study is made possible by the generous support of the American people through the United States Agency for International Development (USAID) under the cooperative agreement no. AIDOAA-A-15-00039. The contents are the responsibility of the University of Florida and do not necessarily reflect the views of USAID or the US Government.

Open Access This article is licensed under a Creative Commons Attribution 4.0 International License, which permits use, sharing, adaptation, distribution and reproduction in any medium or format, as long as you give appropriate credit to the original author(s) and the source, provide a link to the Creative Commons licence, and indicate if changes were made. The images or other third party material in this article are included in the article's Creative Commons licence, unless indicated otherwise in a credit line to the material. If material is not included in the article's Creative Commons licence and your intended use is not permitted by statutory regulation or exceeds the permitted use, you will need to obtain permission directly from the copyright holder. To view a copy of this licence, visit http://creativecommons.org/licenses/by/4.0/. 


\section{References}

Adger, W. N., \& Vincent, K. (2005). Uncertainty in adaptive capacity. Comptes Rendus Geoscience, 337(4), 399-410.

Adger, W. N., Dessai, S., Goulden, M., Hulme, M., Lorenzoni, I., Nelson, D. R., Naess, L. O., Wolf, J., \& Wreford, A. (2009). Are there social limits to adaptation to climate change? Climatic Change, 93(3-4), 335-354.

Ali, A., \& Erenstein, O. (2017). Assessing farmer use of climate change adaptation practices and impacts on food security and poverty in Pakistan. Climate Risk Management, 16, 183-194.

Arias, D., Leguía, J. J., \& Sy, A. (2013). Determinants of agricultural extension services: The case of Haiti. LCSSD Food Paper Series. World Bank. Available via Open Knowledge Repository. https://openknowledge.worldbank.org/handle/10986/16291.

Buizer, J., Cash, D. W., \& Council, N. R. (2005). Knowledge-action systems for seasonal to interannual climate forecasting: Summary of a National Research Council, Policy and Global Affairs, Roundtable on Science and Technology for Sustainability. Washington D.C: National Academies Press.

Burton, I., White, R. W., \& Gilbert, F. (1978). The environment as hazard (2nd ed.). New York: Guildford Press.

Carr, E. R., Fleming, G., \& Kalala, T. (2016). Understanding women's needs for weather and climate information in agrarian settings: The case of Ngetou Maleck, Senegal. Weather, Climate, and Society, $8(3), 247-264$.

Carribean Natural Resource Institute (CANARI). (2005). Governance and civil society participation in sustainable development in the Caribbean (CANARI Policy Brief No. 7). Trinidad and Tobago. https://canari.org/wp-content/uploads/2014/09/Governance-and-Civil-Society-Participation.pdf.

Cash, D. W., Borck, J. C., \& Patt, A. G. (2006). Countering the loading-dock approach to linking science and decision making comparative analysis of El Niño/southern oscillation (ENSO) forecasting systems. Science, Technology \& Human Values, 31(4), 465-494.

Catholic Relief Services (CRS). (2016). El Nino and its human toll. Policy Briefing Note p.7. https://www.crs. org/sites/default/files/el-nino-summary.pdf.

Changnon, S. A., \& Vonnahme, D. R. (2003). Impact of spring 2000 drought forecasts on Midwestern water management. Journal of Water Resources Planning and Management, 129(1), 18-25.

Clarkson, G., Dorward, P., Osbahr, H., Torgbor, F., \& Kankam-Boadu, I. (2019). An investigation of the effects of PICSA on smallholder farmers' decision-making and livelihoods when implemented at large scale - The case of northern Ghana. Climate Services, 14, 1-14.

Comoé, H., \& Siegrist, M. (2015). Relevant drivers of farmers' decision behavior regarding their adaptation to climate change: A case study of two regions in Côte d'Ivoire. Mitigation and Adaptation Strategies for Global Change, 20(2), 179-199.

Evans, M., Stoddart, H., Condon, L., Freeman, E., Grizzell, M., \& Mullen, R. (2001). Parents' perspectives on the MMR immunisation: A focus group study. The British Journal of General Practice, 51, 904-910.

Famine Early Warning Systems Network (FEWS NET). (2015). Haiti Rural Livelihood Profiles. https:/fews. net/sites/default/files/documents/reports/Haiti-LH-profiles-2015-04.pdf.

Glaser, B. G., Strauss, A. L., \& Strutzel, E. (1968). The discovery of grounded theory; strategies for qualitative research. Nursing Research, 17(4), 364.

Golnaraghi, M., \& Senior, R. K. (1995). The science of policymaking: Responding to ENSO. Environment: Science and Policy for Sustainable Development, 37(1), 16-44.

Grothmann, T., \& Patt, A. (2005). Adaptive capacity and human cognition: The process of individual adaptation to climate change. Global Environmental Change, 15(3), 199-213.

Karki, S., Burton, P., \& Mackey, B. (2020). The experiences and perceptions of farmers about the impacts of climate change and variability on crop production: A review. Climate and Development, 12(1), 80-95.

Karmalkar, A. V., Taylor, M. A., Campbell, J., Stephenson, T., New, M., Centella, A., Benzanilla, A., \& Charlery, J. (2013). A review of observed and projected changes in climate for the islands in the Caribbean. Atmósfera, 26(2), 283-309.

Lemos, M. C., Kirchhoff, C. J., \& Ramprasad, V. (2012). Narrowing the climate information usability gap. Nature Climate Change, 2(11), 789-794.

Mase, A. S., Gramig, B. M., \& Prokopy, L. S. (2017). Climate change beliefs, risk perceptions, and adaptation behavior among Midwestern US crop farmers. Climate Risk Management, 15, 8-17.

Meinke, H., Howden, S. M., Struik, P. C., Nelson, R., Rodriguez, D., \& Chapman, S. C. (2009). Adaptation science for agriculture and natural resource management-Urgency and theoretical basis. Current Opinion in Environment Sustainability, 1(1), 69-76. 
Moron, V., Frelat, R., Jean-Jeune, P. K., \& Gaucherel, C. (2015). Interannual and intra-annual variability of rainfall in Haiti (1905-2005). Climate Dynamics, 45(3-4), 915-932.

Neelin, J. D., Munnich, Su, H., Meyerson, J. E., \& Holloway, C. E. (2006). Tropical drying trends in global warming models and observations. Proceedings of the National Academy of Sciences, 103, 6110-6115.

Nurse, L.A., R.F. McLean, J. Agard, L.P. Briguglio, V. Duvat-Magnan, N. Pelesikoti, E. Tompkins, and A. Webb, 2014: Small islands. In: Climate Change 2014: Impacts, adaptation, and vulnerability. Part B: Regional Aspects. Contribution of Working Group II to the Fifth Assessment Report of the Intergovernmental Panel on Climate Change [Barros, V.R., C.B. Field, D.J. Dokken, M.D. Mastrandrea, K.J. Mach, T.E. Bilir, M. Chatterjee, K.L. Ebi, Y.O. Estrada, R.C. Genova, B. Girma, E.S. Kissel, A.N. Levy, S. MacCracken, P.R. Mastrandrea, and L.L. White (Eds.)] (pp. 1613-1654). Cambridge: Cambridge University Press.

Patt, A., Suarez, P., \& Gwata, C. (2005). Effects of seasonal climate forecasts and participatory workshops among subsistence farmers in Zimbabwe. Proceedings of the National Academy of Sciences, 102(35), $12623-12628$.

Peterson, T. C., Taylor, M. A., Demeritte, R., Duncombe, D. L., Burton, S., Thompson, F., Porter, A., Mercedes, M., Villegas, B., Semexant Fils, R., Tank, A. K., Martis, A., Warner, R., Joyette, A., Mills, W., Alexander, L., \& Gleason, B. (2002). Recent changes in climate extremes in the Caribbean region. Journal of Geophysical Research-Atmospheres, 107(D21).

Rauscher, S. A., Giorgi, F., Diffenbaugh, N. S., \& Seth, A. (2008). Extension and intensification of the MesoAmerican mid-summer drought in the twenty-first century. Climate Dynamics, 31, 551-571.

Slovic, P., Kunreuther, H., \& White, G. (2016). Decision processes, rationality and adjustment to natural hazards. In The perception of risk (pp. 39-69). London: Routledge.

Smucker, P., \& Nowak, J. (1981). The role of rural Haitian women in development. In Port-au-Prince. Haiti and Washington, DC: Report to USAID.

White, T. A. (1993). Study on the role of women in agriculture, the socio-economic status of women, and the status of SCF-supported 'Groupement' and Women's clubs in Maissade, Haiti. Haiti: Save the Children Federation.

World Bank. (2018). Mobile cellular subscriptions (per 100 people) - Haiti. International Telecommunication Union, World Telecommunication/ICT Development Report and database. https://data.worldbank. org/indicator/IT.CEL.SETS.P2?locations=HT.

World Bank. (2019). World Bank to Strengthen Human Capital and Climate Resilience in Haiti. Press release NO: 2019/180/LAC. http:/www.worldbank.org/en/news/press-release/2019/05/17/world-bank-tostrengthen-human-capital-and-climate-resilience-in-haiti

World Food Program Haiti. (2019). Country Brief April 2019. https://reliefweb.int/sites/reliefweb. int/files/resources/Haiti\%20Country\%20Brief\%20April\%202019_RB_original.pdf. Cited on June 20, 2019.

Zelaya, P., Harder, A., \& Roberts, T. G. (2017). Small-scale farmers' decision-making for crop selection and production practices in northern Haiti. Journal of International Agricultural and Extension Education, 24(2), 22-34.

Publisher's note Springer Nature remains neutral with regard to jurisdictional claims in published maps and institutional affiliations. 